\title{
Configurações
}

Revista Ciências Sociais

26 | 2020

Economy and Society: politics, practices, agents, and institutions

\section{Who Rules the Airwaves? The Influence of Radio in the 1946 and 1948 Argentine National Elections}

Quem manda nas ondas sonoras? A influência da rádio nas eleições nacionais argentinas de 1946 e 1948

Qui dirige les ondes? L'influence de la radio lors des élections nationales argentines de 1946 et 1948

\section{Nathan Widener e Jari Eloranta}

\section{OpenEdition}

\section{Journals}

\section{Edição electrónica}

URL: http://journals.openedition.org/configuracoes/10387

DOI: 10.4000/configuracoes.10387

ISSN: $2182-7419$

\section{Editora}

Centro de Investigação em Ciências Sociais

\section{Edição impressa}

Paginação: 125-150

ISSN: 1646-5075

\section{Refêrencia eletrónica}

Nathan Widener e Jari Eloranta, « Who Rules the Airwaves? The Influence of Radio in the 1946 and 1948 Argentine National Elections ", Configurações [Online], 26 | 2020, posto online no dia 16 dezembro 2020, consultado o 21 dezembro 2020. URL : http://journals.openedition.org/ configuracoes/10387; DOI : https://doi.org/10.4000/configuracoes.10387 
Widener, Nathan; Eloranta, Jari - Who Rules The Airwaves? The Influence of Radio in the 1946 and 1948 Argentine National Elections. Configurações, vol. 26, 2020, pp. 125-150.

\title{
Who Rules the Airwaves? The Influence of Radio in the 1946 and 1948 Argentine National Elections
}

\author{
NATHAN WIDENER * \\ Pellissippi State Community College \\ JARI ELORANTA** \\ University of Helsinki
}

\begin{abstract}
Our goal in this article is to examine what role radio played in the Argentinian elections of 1946 and 1948 - i.e., whether this medium helped Juan Domingo Perón secure his electoral victories. Through the evaluation of the preceding elections and the emergence of radio in Argentina, the analysis of the two elections will be conducted both qualitatively, via discussion of the political economy surrounding the elections; as well as quantitatively, through an examination of the determining factors of their respective outcomes. We argue that radio played a pivotal role in the elections, especially in 1946, since it provided an effective advertising and public opinion tool for Perón. Moreover, the nationalization of the radio networks in the same period helped to enable Perón's control going forward, both among certain voting constituencies and certain regions.
\end{abstract}

Keywords: Peronism, radio, mass media influence, Argentine elections.

1 The authors would like to thank several people for their contributions to this research. First, we would like to thank Lee Alston and Andrés Gallo for sharing their data and insights, as well as several conference discussants (especially Anne McCants and Michael Haupert). We would also like to express our gratitude to: Mary Ann Widener, who created the maps and visual analytics; to the research librarians at Appalachian State University, especially John Wisewell and University of North Carolina Chapel Hill, especially Teresa Chapa; and to Christopher Ellison as an editor.

* E-mail: nrwidener1@pstcc.edu

** E-mail: jari.eloranta@helsinki.fi 


\section{Resumo}

Quem manda nas ondas sonoras? A influência da rádio nas eleições nacionais argentinas de 1946 e 1948

O presente artigo visa examinar a questão do papel desempenhado pela rádio nas eleições de 1946 e 1948: ou seja, examinar se esse meio de comunicação ajudou ou não Juan Domingo Perón a conquistar o poder pela via eleitoral. Ao avaliar as eleições anteriores e a emergência da rádio na Argentina, a análise destas duas eleições realizar-se-á tanto qualitativamente, através de uma argumentação da economia política envolvendo as mesmas; como quantitativamente, ao examinar os fatores determinantes dos seus respetivos resultados. Argumentamos que a rádio desempenhou um papel fundamental nas eleições, sobretudo em 1946, porque forneceu um instrumento de opinião pública eficiente para Perón. Aliás, a nacionalização das redes radiofónicas no mesmo período contribuiu para que Perón pudesse controlar, daí em diante, quer certos eleitorados quer certas regiões.

Palavras-chave: Peronismo, rádio, influência dos media, eleições argentinas.

\section{Résumé}

Qui dirige les ondes ? L'influence de la radio lors des élections nationales argentines de 1946 et 1948

Notre objectif dans cet article est d'examiner quel rôle la radio a joué dans les élections argentines de 1946 et 1948 - en d'autres termes, si ce média a aidé ou non Juan Domingo Perón à obtenir ses victoires électorales. En évaluant les élections précédentes et l'émergence de la radiodiffusion en Argentine, ces deux élections seront analysées aussi bien qualitativement, par le biais d'une argumentation de l'économie politique concernant celles-ci que quantitativement, grâce à un examen des facteurs déterminants de ses résultats respectifs. Nous soutenons que la radiodiffusion a joué un rôle fondamental lors des élections, surtout en 1946, car elle a fourni un outil efficace de publicité et d'opinion publique pour Perón. Par ailleurs, la nationalisation des réseaux radio au cours de la même période a contribué pour le contrôle de Perón, tant dans certaines circonscriptions électorales que dans certaines régions.

Keywords: Péronisme, radio, influence sur les médias, élections argentines.

\section{Introduction}

In Latin America the media, in particular radio, has played a major role in politics, both in the past and more recently. For example, Brazilian Pres. Jair Bolsonaro has used mass media as a way to engage the electorate and attack the press as a way to consolidate political power. Pres. Hugo Chávez in Venezuela used radio to connect to voters throughout the countryside. Brazilian Pres. Getúlio Vargas established radio stations to help disseminate his populist programs to larger audiences in the 1930s through to the 1950s. In Mexico in the 1930s, Pres. Lázaro Cárdenas used 
radio to present political propaganda to help win political support for nationalizing the oilfields. In the $21^{\text {st }}$ century, Ecuadorian Pres. Rafael Correa used weekly radio announcements to connect with voters. The media - whether in the form of newspapers, telegraph, TV, radio, or the Internet - has played a big role in the evolution of democracies over the last 200 years or so (see e.g. Boas, 2005; Brusco et al., 2004). Here we investigate a moment in history when a particular medium, the radio, was just gaining popularity.

We analyze the role radio played in the Argentinian elections of 1946 and 1948, particularly whether this medium helped Perón secure his electoral victories. To do so, we will first examine the period leading up to these two elections, and the spread of radio coverage in Argentina. Then we will put the two elections into qualitative contexts, to be followed by a quantitative analysis of their determinants. We hypothesize that radio played a crucial role. Perón's first election in 1946 holds the most interest for our research because of the massive number of recounts and the fact that this was the first time the populist leader's name was explicitly on the ballot. Following the first election, radio became a state-run tool that provided Perón an effective method to monopolize political advertisements and diminish the opposition's ability to reach potential voters. Information is power, and the person or organization that controls it is able to set the narrative. Our hypothesis is that by looking at radio, we can understand better the broader patterns of Perón's ascendancy to power and the political evolution of Argentine society.

\section{Scholarly perspectives: radio, Perón, Argentine Elections and elec- toral fraud}

Our analysis rests on unpacking four key elements: radio/communications theory, Perón's use of radio, Argentine elections, and electoral fraud. To begin with, the impact of radio on politics and elections around the early to middle $20^{\text {th }}$ century is well-documented. For example, U.S. Pres. Franklin Delano Roosevelt used the radio in his famous "Fireside Chats" to speak to voters as individuals. Radio played an important role in increasing the political support for most New Deal programs. Moreover, counties with more radio listeners received more relief funds, even when other factors are taken into account (Strömberg, 2004). In Italy and Germany, Mussolini's and Hitler's impassioned speaking styles were best suited for frenzied radio broadcasts that contributed to their quick rise to power. Thus, there is a clear relationship between radio and populist politics in the early to mid- $20^{\text {th }}$ century.

Our hypothesis builds on of the scholarship and research about media and politics in the 1940s, particularly Benedict Anderson's seminal work, Imagined Communities (2006). Anderson argued that those who engaged with various types of media became connected to one another in an "imagined community." 
This newly forming community in Argentina was built in part through radio news, music, and sports programs. All of these types of media were means through which Perón was able to reach out and connect to listeners and engage political actors for specific agendas. Their influence on political outcomes, in particular at the ballot box, was clearly among Perón's and Peronists' goals. Both American and Argentine historians agree that the radio played a unique role in Perón's fortunes, yet neither group has attempted to construct the mechanism that Perón used to reach a larger population. One problem is that the historiography is divided into so many different camps that a consensus about mass media and political action becomes difficult to ascertain. For example, Argentine radio historians have focused on two aspects: first, that the radio had a democratizing effect on the population; and second, that Argentine radio history does not have political dimension (Claxton, 2007; Ulanovsky et al., 1996). This creates a tension between the two approaches to understanding how mass media was used by the populist leader.

Traditionally, Peronist historians have never discussed specifically how Perón used the radio in his political propaganda machine. For example, when discussing radio and its importance in the 1946 election, Félix Luna has argued that the radio was the great instrument that Perón used to proselytize. Luna never elaborated on what specific words or images Perón used to activate his listeners. Recently historians of Peronism have attempted to integrate cultural messages on the radio into their analysis, but they have failed to link political action to media expressions. Daniel James incorporated the idea of culture into his study of Peronism by arguing that Perón utilized the heretical language of the tango as a type of identification politics with his listeners (James, 1993: 31).

Pre-Peronist media historians have maintained that radio culture laid the groundwork for populist messaging. Robert Claxton demonstrated that the pre-Peronist radio networks and stations developed programs catering to specific Argentine audiences (Claxton, 2007). The development of four private radio networks in the 1930s inside Argentina (Radio Belgrano, Radio Azul y Blanca, Radio El Mundo, and Radio Splendid, alongside the public network of LRA Radio Nacional) were indicative of this. While Claxton clearly demonstrated the power of radio, he stopped short of discussing its role in Perón's rise and use of radio in 1946. Other Argentine media historians, Matthew B. Karush and Oscar Chamosa, have shown how media created a truly Argentinian cultural nationality that blended both city and country lifestyles (Karush, 2012; Chamosa, 2010). Lastly, Carlos Ulanovsky (1996) has chronicled radio's changes throughout the 20th century, though he is vague about the political implications of these. This article will briefly focus on the political addresses given by the candidates, although we advocate for further research on the actual radio content.

Democracy in Latin America is a complicated phenomenon, due to the variety of political parties and cultural components. For example, many political scientists consider Chile to have had the longest continuing democracy in 
Latin America, despite its authoritarian interludes. On the other hand, Brazil had a monarchy until 1889 and struggled with military dictatorships throughout the twentieth century, yet today Brazil is considered an important developing-country democracy. Howard J. Wiarda and Harvey F. Kline (1985) have argued that Latin American political processes are grounded in a set of assumptions and characteristic features that emphasize hierarchy, authority, personalism, family and kinship ties, centralization, the need for organic national unity, elaborate networks of patron-client relations, patrimonialism, and a pervasive pattern of vertical-corporate organization.

The turn of the $20^{\text {th }}$ century brought changes in the political realm for many Latin American countries. Peter H. Smith (2005) has contended that there were four types of governments in the $20^{\text {th }}$ century: electoral democracy, electoral semi-democracy, oligarchic republicanism, and non-democracy. Following independence, Argentina followed the process that Smith laid out. Argentina in the early $19^{\text {th }}$ century was a divided government of liberals and conservatives that enabled the rise of the provincial leader Juan Manuel de Rosas as the central political figure. Rosas reshaped the democracy of Argentina by establishing a military dictatorship that squashed political freedoms, such as freedom of the press and assembly. Rosas represented the oligarchic republicanism and non-democratic features of Argentine political life. Following his death, democratic rule returned to Argentina with the election of Domingo F. Sarmiento in 1868. The flowering of late $19^{\text {th }}$ century democracy in Argentina would continue to evolve to incorporate new political parties in the early $20^{\text {th }}$ century (Rock, 1985: 193).

Throughout the 1920s, Argentina experienced economic growth, mostly due to rising prices, foreign investment. This period saw the rise of politicians who were more oligarchic in nature: established leaders such as Marcelo Torcuato de Alvear and Hipólito Yrigoyen. The onset of the Great Depression in 1929 ushered in the oligarchic approach to democracy in Argentina. Conservative factions began to seize power throughout the 1930s, with leaders repeatedly rigging elections to keep themselves in power (Rock, 1985: 214). The rising influence of the Army in Argentine politics came directly from the stagnation in exports. The military dictatorship that emerged in 1930 was led by military leaders such as the army's Gen. José F. Uriburu (see esp. Potash, 1969). By the middle of the 1940s, Argentina had another military coup of young officers; one of the central leaders of this coup was Juan Perón. The rise of Juan Domingo Perón to presidency was his service as Secretary of Unions to eventually becoming Secretary of War. After 1945, the military resolved to return political power to the people and offer the first free election for leadership since the 1930s.

Central to our analysis is the question of fraud in the elections, whether the official results were credible and thus suitable for further quantitative analysis. There were multiple levels of fraud. The political markets in Argentina have traditionally been riddled with corruption and patronage relationships (Calvo \& 
Murillo, 2004). For example, the dictatorship of Juan Manuel de Rosas in the mid-19th century arose from his patron-client relationship with gauchos throughout the countryside. This is a type of institutionalized fraud that is very difficult to measure. The patron-client relationship was a way that fraud continued into the 20th century. Political parties, unions, and class structures have become the cornerstones of a political system that has depended on patron-client relationships and perpetrated fraud in the political sphere (On similarities with the Perón period and more modern Argentinian elections, see e.g. Gibson \& Suárez-Cao, 2010; Levitsky, 2003; Little, 1973a, 1973b; Snow, 1969). As a way to combat patron-client elections, Argentines pushed for compulsory voting for men over 21 (Rock, 1985: 185). Despite this, there was systemic fraud throughout the 1930s with political bosses attempting to retain power, and with such measures including switching ballot boxes, arrests of opposition members on trumped-up charges on election day, police confiscating opposition ballots, falsifying voter rolls to enable dead citizens to vote for political bosses, bribing voters, and having more votes than voters. As Lee Alston and Andrés Gallo (2010) have pointed out, while Argentina in the early $20^{\text {th }}$ century was fairly developed economically, it never completed the transition towards full democratic consolidation. It was this situation that provided the opportunity for Perón's rise.

While electoral fraud was a real problem in Argentina, there is another problem concerning the charges of fraud. The losing party would commonly denounce elections as fraudulent simply because they did not win. The Radical Party throughout the 1920s and 1930s openly complained of fraud in elections that they lost. These charges of fraud can then compound the impact of actual cases due to the zero-sum nature of elections. What makes the 1946 presidential election unique is the meteoric rise of Perón and the triple recounting of election results at the jurisdictional level. Neither Perón nor his opposition claimed that there was any fraud in this election. While neither side claimed fraud, it is important to point out that historically fraud occurred often in Argentine elections and must be considered as a factor when analyzing historical data. Alston and Gallo (2010) actually created a measure to quantify the various levels of fraud in jurisdictions throughout Argentina in the run-up to the 1946 election, which is a measure we use in this article as well.

Our analysis attempts to bridge these divides within the historiography and verify some of the broader claims. We argue that radio helped form communities of listeners who were engaged with the message presented. We also investigate whether individual radio networks, such as Radio Belgrano, had a more substantial impact on voting behavior. Radio certainly appeared to help Perón to gain political support from the population by recreating the patron-client model of democracy and eventually authoritarian political economy in Argentina. 


\section{Argentina's modernization, elections, and radio}

Since Spanish colonization, Argentina has suffered from internal divisions that made it difficult for a democracy to emerge. In the late-19 ${ }^{\text {th }}$ century, Argentina's policies dramatically changed to foster industrialization by encouraging immigration from southern European countries. Many of the immigrants stayed within Buenos Aires to become part of the working classes (Sarmiento, 1998). In 1912, the Sáenz Peña Ley extended universal mandatory male suffrage throughout Argentina, affording immigrants the right to vote. The workers outside the industrial zones were primarily indigenous and mestizo, and they worked for agricultural producers. The rural and urban working classes had little interaction with each other due to differences in geography, cultural affiliation, and job skills.

Argentina developed a native radio industry early in the 1920s that served as the basis for the country to have the second-largest radio network in the world by the late 1930s (Claxton, 2007). In the early days, radio was primarily an outgrowth of newspapers and government organizations. In the 1920s, radio stations created content for small niche audiences. Folk, tango, and jazz were the predominant types of music played on early radio and demonstrated a cross-cultural reach to both the urban and rural working classes. Programs such as Chispazos de Tradición (Sparks of Tradition) incorporated folk music and melodrama storylines from urban tango lyrics (Karush, 2012; Claxton, 2007). Thus, radio helped facilitate the emerging Argentine national identity that incorporated images from the rural gaucho like Martín Fierro, and urban styles like the tango.

In the 1930s, the Argentine government became interested in regulating radio content. Smaller radio stations could not comply with all the new rules. Owners like Jaime Yankelevich bought fledgling radio stations and incorporated them into larger networks. In the 1940s, radio personalities such as the famous tango singer Carlos Gardel and actress Eva Duarte became household names in Argentina. As seen in Table 1, radios were fairly ubiquitous in interwar Argentina, with over a million receivers by the 1930s. Their number grew fairly slowly in the 1940s, possibly due to impacts of the war. However, the number of receivers at least doubled from the mid-1940s to the mid-1950s, thus underscoring the growing impact of this medium. The steady growth in radio sets after Perón's election also mirrored the modest economic growth during the postwar period. Moreover, Table 1 highlights the speculative nature of the estimates on the number of radios in Argentina. 
Table 1: Number of Radio Receivers in Argentina (Based on Several Sources), 1934-1955

\begin{tabular}{|r|r|r|}
\hline YEAR & $\begin{array}{c}\text { Number of Radios } \\
\text { (Banks) }\end{array}$ & $\begin{array}{r}\text { Number of Radios } \\
\text { (Other Estimates) }\end{array}$ \\
\hline 1934 &.. & $1,200,200$ \\
\hline 1935 &.. &.. \\
\hline 1936 &.. &.. \\
\hline 1937 &.. &.. \\
\hline 1938 & $1,100,000$ &.. \\
\hline 1939 & $1,112,000$ &.. \\
\hline 1946 & $1,200,000$ & $1,300,000^{*}$ \\
\hline 1947 & $1,300,000$ &.. \\
\hline 1948 & $1,400,000$ &.. \\
\hline 1949 & $1,500,000$ &.. \\
\hline 1950 & $2,200,000$ &.. \\
\hline 1951 & $2,327,000$ &.. \\
\hline 1952 & $2,454,000$ & $1,500,000 \pm$ \\
\hline 1953 & $2,582,000$ &.. \\
\hline 1954 & $2,710,000$ &.. \\
\hline 1955 & $2,838,000$ & $2,700,000^{+}$ \\
\hline
\end{tabular}

Sources: Banks (1973).

Notes: *Data and Rates of Radio Stations in the Other American Republics and Puerto Rico (1945), 10); \pm "What Are the Facts About Radio Abroad? (1952), 230; + World Communications (1956).

We can put the spread of radios into a better context by converting the numbers into per capita terms and by comparing the number of radios to other media, such as telegraphs and telephones. Of course, these are not directly comparable mediums since, for example, telephones are more of a personal communication device, somewhat similar to telegraphs. But they do illustrate the importance of radio alongside other communications technologies. Radio broadcasts were geared for the broad masses and could be financed by advertising. 
Figure 1: Telegrams, Telephones, and Radio Receivers per Capita in Argentina, 1870-1973

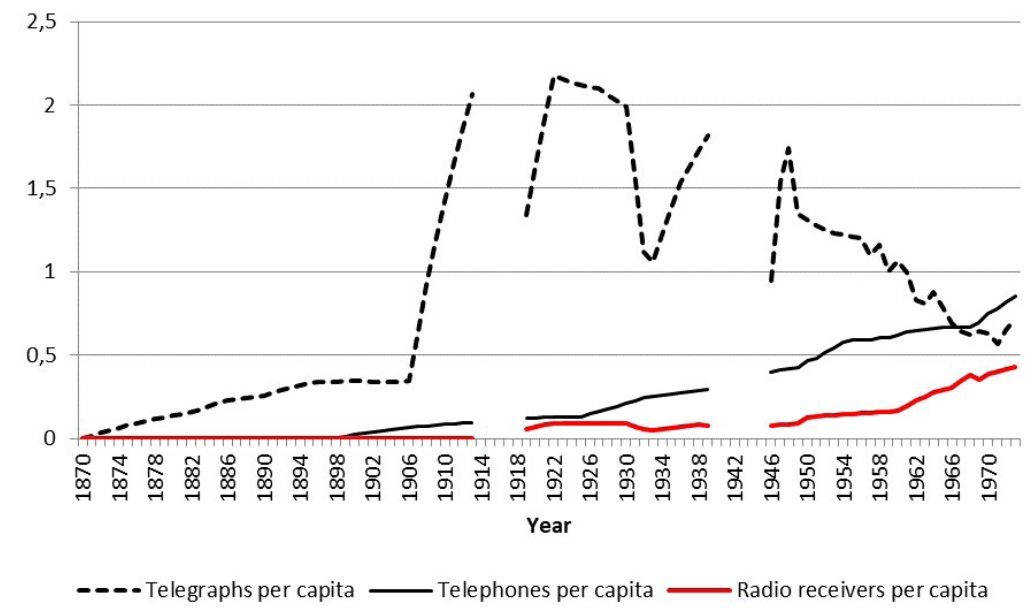

Source: Banks (1973).

As seen in Figure 1, telegraphs per capita were much higher than were telephones or radios, which make sense given the order of appearance of these technological innovations, respectively. While the number of telegraphs in Argentina peaked by the time of the First World War, radios and telephones began to spread only after the 1920s. However, the rise in the number of telephones was much earlier than that of the radio, with the latter only expanding steadily beginning in the 1940s. The spread of electricity was also vital.

The period from 1930-1946 is known as the década infame (decade of infamy) because of its sluggish economic growth, high unemployment, and rule by military dictatorship (Rock, 1985: 214). The Argentine economy was heavily tied to that of England following World War I. The political instability of Yrigoyen's presidency enabled the military to step in and take control of the country in 1930. The military dictatorship allowed for parliamentary elections but did not allow for significant changes to the status quo to be enacted. A new coup was staged in 1943 , led by young officers. The newly-formed government solidified leadership in 1944, under Gen. Farrell. One of the most promising stars within the government was Col. Juan Domingo Perón, who was the Secretary of Labor, Minister of War, and Vice President. The Farrell government was unstable at the top, however, and thus between 1943 and 1945, Perón gained more political power and influence. He especially relied on the emerging trade unions to stabilize his political power in the country. This set the stage for the elections in 1946. 
Figure 2: GDP per Capita for Argentina, Brazil, and Chile, 1875-2010

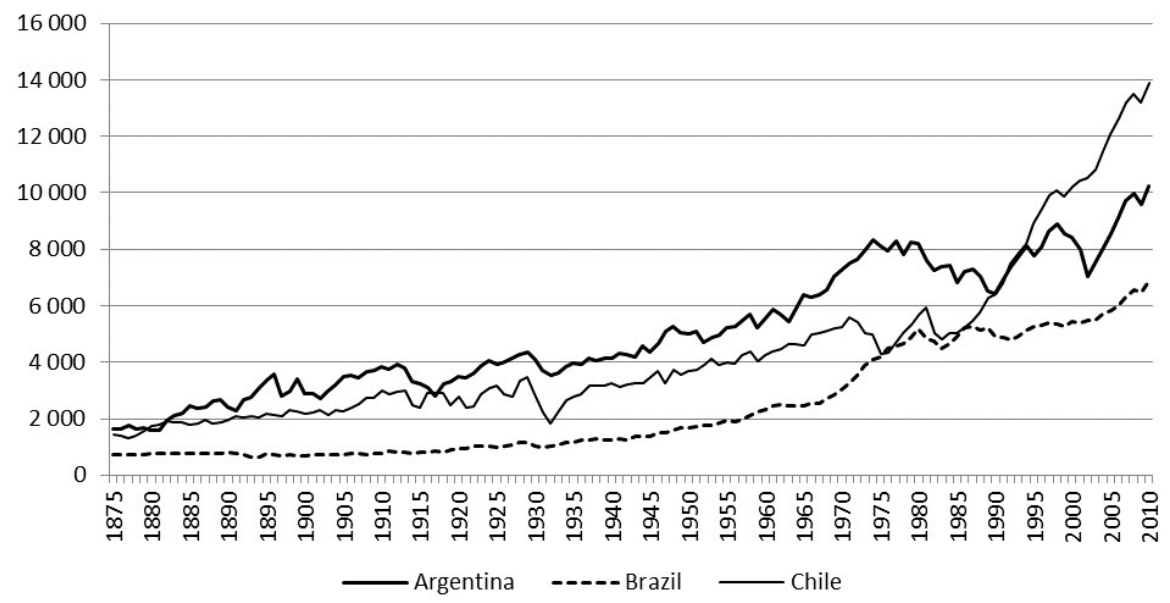

Source: Bolt \& van Zanden (2013).

How does Argentina fare in comparison with other South American economies, like Brazil and Chile? From that perspective, its 1930s economic performance does not look quite as bad. For example, as seen in Figure 2, Argentina developed almost in tandem with Chile, while maintaining a lead in terms of real GDP per capita. The Great Depression slump hit Chile harder than Argentina and the latter's recovery was more even. Brazil was substantially behind these two economies in the 1930s, though the Brazilian economy was not nearly as badly hurt by the Depression. The Argentinian economy did not experience a major downturn during the Second World War, but the fairly flat growth in the 1940s that had the potential to impact the elections too.

It is worth noting, that Argentina held democratic elections throughout the $19^{\text {th }}$ century, but most of these elections were dominated by the patron-client relationships, rather than addressing national problems. With large numbers of European immigrants in the late $19^{\text {th }}$ century, the political landscape shifted towards open elections. Many members of the working classes supported the Radical Civic Union (Radical Civic Union, or UCR), while conservative factions in Argentina took control of the Elections Board, thereby controlling who voted and whose vote counted (Alston \& Gallo, 2010). The counter-push by Conservatives to remain in power resulted in fraud in the elections of the late 1920s and 1930s.

The earlier elections (i.e., before 1946) can be examined in the microcosm of the Federal Capital district, as seen in Table 2. Overall, in 1928, 1931, and 1937, 
there was a clear winner in these elections, which may be an indicator of electoral fraud. In turn, in 1942, the vote was much closer. As evidenced by the coefficient of variation, we see much more variation in the vote totals of the lower vote-getting parties. Again, this may (or may not) be merely a sign of electoral fraud among the highest vote-getting parties, since one typically might expect variation among districts.

Table 2: Distribution of the Vote between the Three Biggest Parties in the Buenos Aires Barrio, 1928, 1931, 1937, 1942

\begin{tabular}{|r|r|r|r|r|}
\hline Year & Three Biggest Parties & Total \# of Votes & \% of Total Vote & $\begin{array}{c}\text { Coefficient of Varia- } \\
\text { tion among Districts }\end{array}$ \\
\hline 1928 & UCR & 151,313 & 61.7 & 0.06 \\
\hline & UCR (Antip) & 59,873 & 24.4 & 0.19 \\
\hline & Socialists & 33,959 & 15.5 & 0.19 \\
\hline 1931 & Justo-Roca & 85,456 & 29.3 & 0.23 \\
\hline & Justo-Matienzo & 39,632 & 13.6 & 0.18 \\
\hline & Social Democrat Alliance & 166,353 & 57.1 & 0.14 \\
\hline 1937 & Alvear-Mosca & 256,407 & 65.3 & 0.07 \\
\hline & Ortiz Castillo & 110,225 & 28.1 & 0.19 \\
\hline Socialists & 26,021 & 6.6 & 0.29 \\
\hline 1942 & PE & 142,061 & 39.5 & 0.14 \\
\hline & UCR & 124,340 & 34.6 & 0.11 \\
\hline & Conc. & 93,301 & 25.9 & 0.24 \\
\hline
\end{tabular}

Sources: Data provided by Alston \& Gallo (2010).

Note: Highest values for each year in bold; coefficient of variation = standard deviation / mean and is a standardized measure of dispersion. All the abbreviations are explained in the text of the article.

It is well known that the Argentine electoral system certainly had electoral fraud built into it. The quantification of the levels of fraud is, naturally, more difficult. Alston and Gallo (2010) attempted to quantify and measure fraud quantitatively. By looking at previous elections alongside agricultural and census data, they created a fraud variable, calculated as difference in voting for the Radical Party in 1938 and 1940. What is striking is that most of the fraud was concentrated in the province of Buenos Aires, and not in other urban centers such as Córdoba. This map (see Figure 3) demonstrates that fraud was not a universal phenomenon across Argentine jurisdictions, and points to larger questions of methodology. Clearly, electoral fraud in Argentina was a significant factor; but as Alston and Gallo's data proves, much more research is needed on this significant historical topic. 
Figure 3: Existence of Electoral Fraud in Argentina in 1946

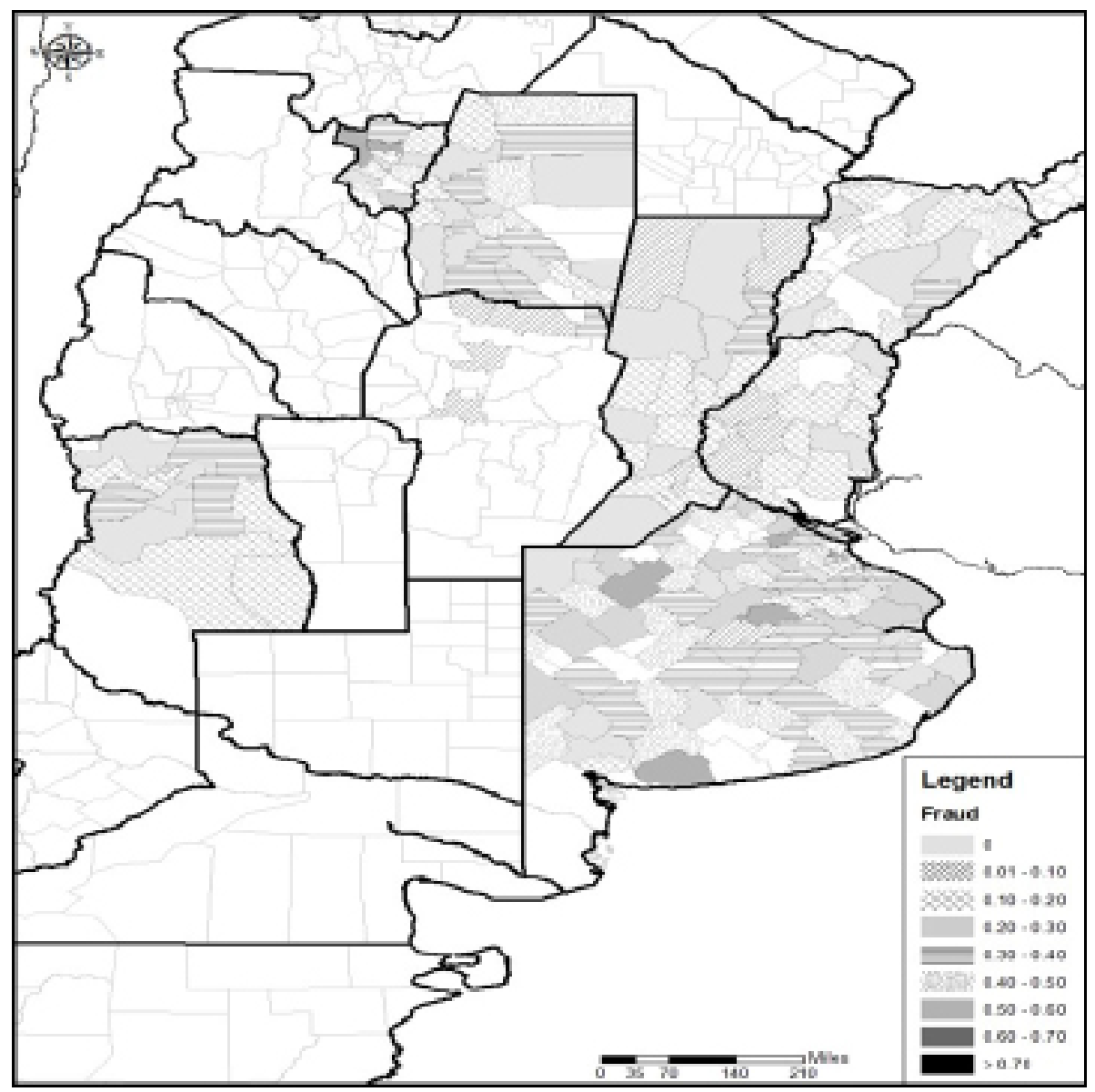

Source: Data provided by Alston and Gallo; mapped by Mary Ann Widener.

Electoral fraud is important to the overall story of the 1946 election. The previous elections in the 1930s demonstrate that fraud was a key factor in determining their respective winners. Alston and Gallo argue that the 1946 election was a fairly clean one, but that fraud in the past changed the beliefs of people who turned to the populist Perón. This is a significant factor since Perón's command of unions gave him the ability to establish a traditional patron-clientele relationship. In addition, Perón thus had a significant electoral bump because of his ability to court certain voters. This also helped Perón legitimize his election and minimize allegations of fraud, as more voters were coming around to his side. The double- and 
triple- counted electoral returns also helped reduce claims of fraud ("El Resultados de Elección en 1946," La Prensa, Buenos Aires, February 28, 1946; Alston \& Gallo, 2010). But what other factors explained his victory in the presidential election of 1946 ?

\section{The 1946 elections}

By the middle of 1945, tensions within Argentina became so acute that people demanded democratic elections. World War II was almost finished, and many Argentines looked back to the end of the World War I and feared economic stagnation and political instability. The return to the idea of democratic elections after 16 years under military rule was a dramatic event. The political contenders were Juan Perón for the Labor Party and José Tamborini for the Democratic Union.

The Democratic Union (Unión Democrática) represented a hodgepodge of previous political parties in Argentina. The majority of the members of this newly-formed party were from the Radical Civic Union (UCR), which was the party of Yrigoyen. The military coup of the 1930s fractured the UCR's political power base by forcing the party to move too far to the left (Luna, 1969: 28). The UCR and diverse other groups, such as conservatives, Communists, Socialists, Democratic Nationalists, and former UCR members, formed the Democratic Union in 1945 (Rock, 1985: 261).

Another central problem for the Democratic Union was their use of competing news narratives. In fact, the Democratic Union used newspapers as their primary method to reach voters. Many of the speeches given by Tamborini and Democratic Union supporters were detailed policy descriptions that were not engaging for radio listeners. The Democratic Union had equal access and time on the radio, and failed to connect to listeners due to their presentation style (Luna, 1969: 453). Many of the Democratic Union attacks were embedded in the middle of speeches, a style that did not work for radio addresses. For example, one of the biggest ways that the Democratic Union attacked Perón was to level the criticism that the Farrell regime favored Nazi Germany. The Democratic Union extrapolated that Perón favored the Germans because of his high rank within the Farrell regime (Luna, 2000). Newspapers then picked up the major attack as the main newspaper headline: "Perón Favors Nazi Policies" ("Las Elecciones Presidenciales en la Pais," La Prensa, Buenos Aires, April 9, 1946). This type of media strategy represented the traditional use of media in Argentina.

Perón's political campaign in 1946 was likewise very different from Tamborini's. On October 9, Juan Domingo Perón resigned as Vice-President and Secretary of Labor of the Farrell regime. In Perón's farewell speech, the subtext linked Perón's political fate to the working class (Mercado, 2013; Plotkin, 2002: 52). The run-up to 
the election demonstrated Perón's use of the radio as a campaign tool. While there were stipulations for equal airtime for political candidates, that line became increasingly unclear due to the relationship between Perón and Eva Duarte. She was one of the stars of Argentine radio by 1945, and it is plausible that this had a significant impact on the presidential election. The military placed Perón in jail on October 13,1945 because they saw him as too charismatic. Over the next few days, many listeners went to the radio to get news of the leader. Radio became the rallying point for demonstrators, with daily announcements for people demanding Perón's release from jail. The political pressure reached a boiling point on October 17, 1945, when Farrell decided to release Perón. At 9:30 in the evening, people had begun to use their radios to tune in for regular updates (Luna, 1969: 348). Finally freed, Perón emerged from the Casa Rosada to give a speech directed at the estimated 300,000 demonstrators immediately in front of him in the Plaza de Mayo.

The radio transmissions represented a connection between Perón and working-class voters. He masterfully used the medium, yelling into the microphone, demonstrating his passion for the people. Perón used Argentine national symbols, spoke rousingly, and focused on voter needs. The populist focus of the Perón campaign tied into the needs of individuals in every political constituency. For example, when speaking to agricultural workers in La Rioja, Perón spoke of developing agriculture and irrigation; when addressing industrial workers in Buenos Aires, he spoke of more rights and vacation time (Mercado, 2013: 85; Rock, 1985: 254). Perón personally addressed and gained favor from each constituent group. He frequently used nationalistic language, such as the image of the criollo and gaucho in his speeches. The folklore and tango that was present on Argentine radio also helped give Perón a political base on radio, because listeners knew these images and associated Perón with them. He broke down the classic Argentine political methodology of individualized patron-client relationships and the endorsement of newspapers through his use of style and methodology of radio.

Perón won the February 1946 election for many reasons, yet the importance of radio seems to have been substantial. The radio was the place that his lower-class constituents throughout Argentina were able to connect with their would-be leader. Not only did that connection emerge via his speeches, but also the radio celebrity of Eva Duarte linked the populist leader to the radio culture. Perón's use of the radio to broadcast his thoughts and agenda are all reasons for a critical examination of how important a factor radio was in the election of 1946, and indeed, afterwards. 


\section{The 1948 elections and beyond}

Argentina experienced changes in international prices of cattle exports that caused an economic boom. This boom was not due to Perón's policies, but many at the time accredited this swift change to the charismatic leader. The First Five-Year Plan, from 1946-1951, was the beginning of Perón's economic agenda that favored the lower classes. The Argentine government used export profits to subsidize lower class wages. Argentina's exports totaled approximately \$1.6 billion in 1948, contributing to excess capital that could be redistributed via the Peronist policies (Milanesio, 2013). The transfer of economic power to the lower classes possibly helped increase consumer purchasing power from 1946 to 1948, and certainly increased Perón's popularity among the masses, which also helped make radios more widely available. Thus, the redistribution of wealth helped more people engage with mass media and increased pro-Perón electoral participation.

Perón also saw the expansion of voting rights to women in the Argentinian territories in the South and the North as a method to gain votes, with Eva Perón's support. The 1947 Argentine Census revealed a substantial population in the territories that did not enjoy political suffrage (IV Censo General de la Nación, 1947; Miller, 1979: 51 - the indigenous people of Chaco and Formosa regions were firmly in Perón's camp). Perón's vocal support of voter expansion to both territorial populations and women also helped garner the populist leader new constituents with more potential political support. There were also radio reforms that occurred between 1946 and 1948 that were reinforced these developments. In June 1947, Perón scheduled a radio address to send Eva to Europe. In the middle of the address, on Radio Belgrano, a voice interrupted the transmission and said, "Don't believe any of his lies" (Luna, 2000: 92). Perón's response over the next few months was the purchase of the radio network and subsequently all private radio networks throughout Argentina. By the end of 1948, radio networks inside Argentina were state ran, thus in the hands of pro-Peronists.

After assuming the presidency and gaining control over all radio networks in Argentina, Perón sought even more political power. One of his biggest problems with the 1853 Constitution pertained to the two-term limit for presidents. He started advocating amendments to the Constitution so that it would uphold more Peronist priorities. In 1948, the Peronist Party won enough votes in the Congress to allow a national referendum to change the Constitution. The fight boiled down to Perón against the UCR. The same tactics were used by both sides, except that the UCR had less access to radio networks. They understood that access to an entire media platform meant their efforts to engage newspapers were redoubled. One of the key issues attached to the ballot was women's suffrage to be enacted in the Constitution, advocated for by Eva Duarte and Juan Perón. The voting districts had the same boundaries as in the 1946 election. When the final vote was 
tallied, the Peronists won, and by 1949 had changed the Constitution in ways that deeply affected subsequent elections.

The period from 1948-1952 was devoid of major national elections; there were a few gubernatorial, senate, and congressional elections, but nothing on a nationwide scale. The rest of Perón's presidency was spent consolidating political and media power into the hands of a smaller and smaller elite. In 1950, the Visca Commission was turned into a witch hunt to purify the Peronist party of dissidents, which also started the process of a government takeover of newspapers. By 1952, Peronists limited opposition voices through ownership of all major newspapers in Argentina. The push to integrate newspapers into the Peronist state can be seen as a direct result of the 1948 political attacks leveled against Perón by newspaper editors. Also, during this time period the government gerrymandered political jurisdictions to create more favorable Peronist strongholds (Luna, 2013: 167-168). The takeover of news media and redrawing of political jurisdictions consolidated power in Perón's hands and resulted in his second presidential term, beginning in 1952. Like many authoritarian figures of his time and since, he managed to subjugate the media and elections under his control, at least for the time being.

While Perón's power grew because of mass media domination, the economics underlying his government's expansion brought on the final collapse of the Peronist government in 1955. The export boom of the late 1940s quickly turned into a crunch in 1950, when the United States outsold Argentina in terms of cattle exports to Europe. Perón's investment in the industry did not allow the government to recuperate its initial losses, thus the period from 1952-1955 was saw a sluggish economy. Audiences started to get turned off by the Peronist messages. The curtain call for Perón turned out to be his attacks on the Catholic Church, a move that gained the attention of the military, and particularly, the Navy, who finally removed him from power in 1955. The return of Perón in 1973 did not mean the return of stability; after a year, the populist leader died in 1974, at the age of 76 .

\section{Quantitative perspectives on the 1946 and 1948 elections}

The Argentinian elections in the 1940s have rarely been analyzed using any quantitative methods or sources. One of the few exceptions is the aforementioned study by Alston and Gallo (2010). They discovered that the electoral system was steeped in fraud, especially during the 1930s, and that this created an informal institutional path going forward. The brief attempt by Pres. Roberto María Ortiz in the 1940s to stop the fraud end with his demise. The military coup of 1943 facilitated Perón's rise and the normalization of this fraudulent system through the 1940s and 1950s. Alston and Gallo also tested empirically whether fraud was a factor in the 1946 elections. They concluded, based on a jurisdiction-level analysis of votes, that Perón's electoral victory depended on several economic and political-economy variables (such 
as industry and presence of cattle) as well as fraud. However, they only analyzed the 1946 election. Thus, we test the determinants of the 1946 and 1948 elections further, to see what role radio played in them. We are more cautious in interpreting the 1946 election as a fraudulent one and maintain that the nationalization of radio ownership solidified Perón's position by the 1948 elections. The elections of the 1950s were not national elections and were likely highly impacted by complete state media control, and thus not suitable for comparative analysis.

It is fairly obvious that control over the radio network, especially via ownership, influenced the elections after 1946. The ownership balance of radio stations changed completely between 1946 and 1948, as shown in Table 3. The nationalization of radio stations proceeded rapidly because Perón used the radio speech attack in a 1947 radio transmission as grounds to take over all radio networks, and most Argentine radio stations. By the end of 1947, all but one radio station in Argentina was under Peronist control. Perón's domination of the news media was further cemented in 1950 following the Visca Commission's investigation that resulted in the public incorporation of most major newspapers (Luna, 2013). The domination of all forms of news media meant that the Peronist party had a clear advantage over opposition parties, who were locked out of access to radio and newspapers (Morrow, 1955, "Perón Paper Bars End of Curbs Now: Answer to Foe's Broadcast Says the Opposition Must End Acts of 'War' First," New York Times, July 30, 1955, 34; "Perón Aide Bars Radio Time to Foe: Radical Leader Fails in Bid to Broadcast--Opposition Setting New Policy," New York Times, July 8, 1955, 10).

Table 3: Radio Ownership in Argentina, 1946, 1948, and 1952

\begin{tabular}{|c|r|r|r|r|r|r|}
\hline Radio Station Ownership & 1946 & $\%$ & 1948 & $\%$ & 1952 & $\%$ \\
\hline Private & 44 & 91.7 & 1 & 1.4 & 1 & 1.4 \\
\hline Public & 4 & 8.3 & 72 & 98.6 & 72 & 98.6 \\
\hline Total & 48 & 100 & 73 & 100 & 73 & 100 \\
\hline
\end{tabular}

Sources: Data and Rates of Radio Stations (1945:5-10); Broadcasting Stations of the World (1946:4-9); Broadcasting Stations of the World (1952: 6-11); Broadcasting Stations of the World (1955: 5-10).

As can be seen in Table 4, quantitatively the impact of radio was more pronounced in 1948, yet it varied regionally. In 1946, in some provinces radio actually had a slightly negative impact on voting for Perón. Radio seemed to slightly increase voting for Perón in Córdoba, Salta, and Santa Fe. In 1948, the situation had changed quite dramatically. In most regions, the slight negative correlations had changed to positives. And in Jujuy, La Rioja, San Luis, Santa Fe, and Santiago del Estero, radio was clearly positively correlated with Perón votes. This result matches the visual inspection of Figure 4. We can certainly conclude that the changes in 
votes between 1946 and 1948 were not just the result of massive electoral fraud, since radio seemed to have a more substantial impact in the latter year. Of course, radio by then had been almost completely nationalized, providing a convenient avenue of campaigning for Perón and his government. Moreover, Perón certainly increased his support in certain key rural areas and in certain regions, and radio helped him do that. A caveat applies, of course, since only multivariate analysis of the key components of these voting patterns, which is what we do next, can provide robust results, and we improved the analysis by Alston and Gallo by adding variables missing from their study, such as the number of radio receivers and various census variables. Furthermore, we analyzed the determinants of both elections, in 1946 and 1948.

Figure 4: Radio's Reach in Argentina and Perón's Gains in the Elections from 1946-1948
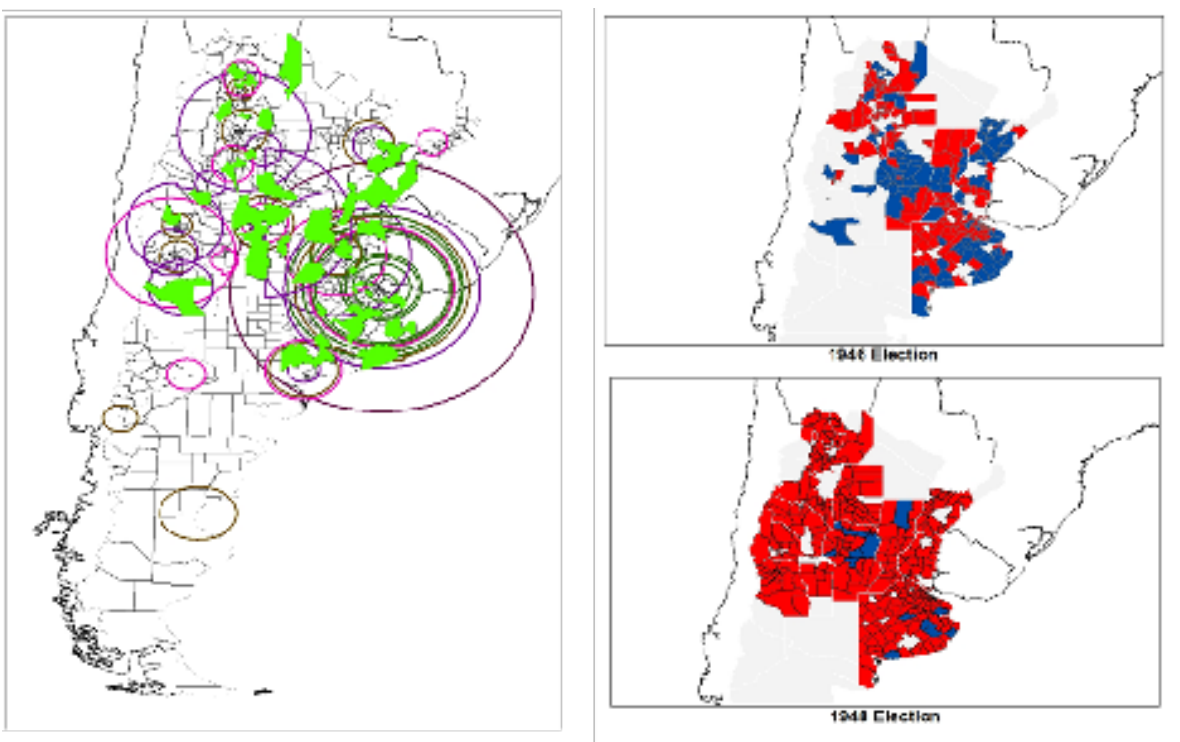

Sources: La Prensa, Various election results between February 24, 1946 and April 15, 1946. La Prensa, Various election results between December 8, 1948 and December 17, 1948. Mapped by Mary Ann Widener.

Note: Perón's gains in 1948, in green (on the left) are juxtaposed with the reach of radio stations and shown for key regions (on the right), Perón as red and opposition as blue. 
Table 4: Correlation between Radio Presence and Perón's Vote Totals in 1946 and 1948

\begin{tabular}{|l|r|r|}
\hline \multicolumn{1}{|c|}{ Province } & Correlation Coefficient in 1946 & Correlation Coefficient in 1948 \\
\hline Buenos Aires & 0.10 & 0.18 \\
\hline Catamarca & -0.03 & -0.16 \\
\hline Córdoba & 0.33 & 0.25 \\
\hline Corrientes & -0.04 & 0.12 \\
\hline Entre Ríos & -0.11 & 0.01 \\
\hline Jujuy & 0.03 & 0.53 \\
\hline La Rioja & 0.19 & 0.44 \\
\hline Mendoza & -0.33 & 0.03 \\
\hline Salta & 0.20 & 0.20 \\
\hline San Juan & -0.11 & 0.21 \\
\hline San Luis & 0.15 & 0.47 \\
\hline Santa Fe & 0.38 & 0.39 \\
\hline Santiago del Estero & 0.15 & 0.42 \\
\hline Tucumán & -0.38 &.. \\
\hline TOTAL & -0.05 & 0.04 \\
\hline
\end{tabular}

Sources: La Prensa, Various election results between February 24, 1946 and April 15, 1946. La Prensa, Various election results between December 8 and 17, 1948.

Note: Pearson correlation coefficient.

Thus, Alston and Gallo analyzed Perón's electoral performance by primarily looking at the persistence of fraud and the impact of various political constituencies: cattle owners who opposed Perón; unions who supported him; and renters who may have opposed landholding elites. They found that the legacy of fraud from the earlier elections had a persistent impact on the 1946 election as well, as did the other explanatory variables. We utilized some of the same variables (number of cattle per farm; proxy for fraud provided by Alston and Gallo; percentage of industrial employment; percentage of renters), as well as several new ones, all at the level of counties/jurisdictions: number of radio stations received in the region (whether Perón's populism was transmitted through this medium, hypothesized as having a positive impact on voting); share of women in the population (the impact of Eva, hypothesized as a positive); unemployment rate (with economic instability possibly benefitting Perón, hypothesized as a positive); and illiteracy rate (not impacted as much by newspapers and written media, hypothesized as a positive for Perón). We also introduced several control variables in our multivariate analysis of counties/jurisdictions: number of businesses; population; population over 
18; and urbanization rate. The dependent variable was the same as in Alston and Gallo's study (namely, voting for Perón), but we expanded their data set to include both rural counties missing from their study as well as to include the 1948 election. This gave us a slightly bigger sample to work with (especially if we did not include the fraud variable they constructed).

Table 5: Factors Affecting Voting for Perón in the 1946 Election

\begin{tabular}{|c|c|c|}
\hline $\begin{array}{c}\text { Independent Variable (in } \\
\text { Jurisdiction) }\end{array}$ & $\begin{array}{c}\text { Specification 1: with Fraud } \\
\text { Variable }\end{array}$ & $\begin{array}{c}\text { Specification 2: without } \\
\text { Fraud Variable }\end{array}$ \\
\hline Cattle per farm & $-0.07 * * *$ & $-0.06^{* * *}$ \\
\hline $\begin{array}{l}\text { Industry employment (as a } \\
\text { share of population) }\end{array}$ & - & - \\
\hline Persons renting property & - & . \\
\hline Number of radios heard & $0.21^{* *}$ & $0.12^{* *}$ \\
\hline $\begin{array}{l}\text { Women's share of the } \\
\text { population }\end{array}$ & - & - \\
\hline Unemployment \% & - & 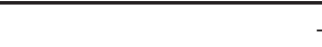 \\
\hline Number of businesses & $0.24 * * *$ & $0.13^{* * *}$ \\
\hline Share of illiteracy & - & 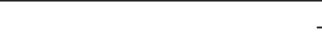 \\
\hline Fraud & $1.85^{* * *}$ & 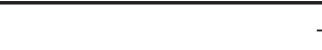 \\
\hline Population & - & . \\
\hline Population over 18 & - & 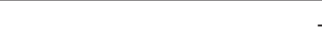 \\
\hline Urbanization rate & - & 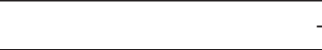 \\
\hline $\begin{array}{l}\text { Interactive variable (num- } \\
\text { ber of radios multiplied } \\
\text { by fraud) }\end{array}$ & $-0.55^{* *}$ & - \\
\hline $\mathrm{N}$ & 192 & 245 \\
\hline Adjusted $\mathrm{R}^{2}$ & 0.42 & 0.10 \\
\hline$F$-statistic & 28.78 & 10.04 \\
\hline
\end{tabular}

Notes: The dependent variable in all specifications is the logistic voting variable (natural logarithm of share of votes for Perón in jurisdiction divided by 1-share of votes for Perón in jurisdiction). All specifications include a constant (not reported here). The estimations include Newey-West consistent standard errors and covariances. All variables (except the fraud variable) expressed in logarithms.

${ }^{*}=$ null hypothesis of no correlation rejected at 10 percent level

** $=$ null rejected at 5 percent level

*** $=$ null rejected at 1 percent level. 
Initially we intended to run these two election years together as a panel, but the dissimilarities between the years suggest that this would not be a worthwhile extension of our work. The results are compiled in Tables 5 and $6 .^{2}$ The persistence of fraud as a structural force in both elections was statistically significant, and it increased from 1946-1948. However, it seems that the interaction of fraud and the impact of radio actually decreased voting for Perón, perhaps suggesting that the abundance of one-sided information lessened the impact of fraud. The impact of owning cattle was the same as in Alston and Gallo's study, as the cattle owners opposed Perón in both elections in a consistent manner. Moreover, in the specifications that mirrored Alston and Gallo, the variables that they used in their study, especially industrial employment, had the expected signs and significance, although these disappeared with the introduction of other control variables.

So, what about the impact of radio? In the 1946 election, radios clearly had a positive and substantial impact on Perón's election numbers, regardless of the specification. Furthermore, in that particular election radio actually reinforced its significance among the illiterate population. What about in 1948? It seems that our earlier findings about there being major differences between these two elections hold true. As seen in Table 6, fraud had a bigger impact on this election, albeit one partially negated by the radio network. In the second specification, radio seems to have had a negative impact on Perón's numbers in 1948, however not in both specifications. Based on the partial correlations discussed earlier, it is quite possible that the impact of radio on voting for Perón increased in some parts of Argentina and not in others. Moreover, a higher illiteracy rate again increased voting for him, this time directly. And the higher the share of women in a given jurisdiction, the higher the propensity to vote for Perón. This may be the "Eva effect" at play, again being transmitted through various media. Also, considering that the opposition had limited access to radios in 1948 and that their only recourse was to newspapers could also help to explain that voters were beginning to not engage as much with radio and to look for plurality of views in other media. 
Table 6: Factors Affecting Voting for Perón in the 1948 Election

\begin{tabular}{|c|c|c|}
\hline $\begin{array}{c}\text { Independent Variable (in } \\
\text { Jurisdiction) }\end{array}$ & $\begin{array}{c}\text { Specification 1: with Fraud } \\
\text { Variable }\end{array}$ & $\begin{array}{c}\text { Specification 2: without } \\
\text { Fraud Variable }\end{array}$ \\
\hline Cattle per farm & $-0.11^{* * *}$ & $-0.10 * * *$ \\
\hline $\begin{array}{l}\text { Industry employment (as a } \\
\text { share of population) }\end{array}$ & - & - \\
\hline Persons renting property & - & - \\
\hline Number of radios heard & - & $-0.23^{* *}$ \\
\hline $\begin{array}{l}\text { Women's share of the } \\
\text { population }\end{array}$ & $0.63^{* * *}$ & - \\
\hline Unemployment \% & - & - \\
\hline Number of businesses & - & - \\
\hline Share of illiteracy & $0.23^{* * *}$ & - \\
\hline Fraud & $1.67^{* * *}$ & - \\
\hline Population & - & $-0.14^{* * *}$ \\
\hline Population over 18 & - & - \\
\hline Urbanization rate & - & - \\
\hline $\begin{array}{l}\text { Interactive variable (num- } \\
\text { ber of radios multiplied by } \\
\text { another variable) }\end{array}$ & $\begin{array}{l}\text { (Fraud) } \\
-0.55^{* * *}\end{array}$ & - \\
\hline $\mathrm{N}$ & 213 & 290 \\
\hline Adjusted $\mathrm{R}^{2}$ & 0.38 & 0.26 \\
\hline F-statistic & 26.55 & 34.09 \\
\hline
\end{tabular}

Notes: The dependent variable in all specifications is the logistic voting variable (natural logarithm of: share of votes for Perón in jurisdiction divided by 1-share of votes for Perón in jurisdiction). All specifications include a constant (not reported here). The estimations include Newey-West consistent standard errors and covariances. All variables (except the fraud variable) expressed in logarithms.

* $=$ null hypothesis of no correlation rejected at 10 percent level

** $=$ null rejected at 5 percent level

$* * *$ null rejected at 1 percent level

Finally, we also tested to see if particular radio networks had a consistent impact, in this case Radio Belgrano and Radio Excelsior, with the latter being the biggest network. In 1946, Radio Belgrano had a large, positive, and statistically significant impact on voting for Perón. Excelsior was not statistically significant. In 1948, however, Belgrano's impact was not statistically significant, whereas Excelsior had a small, negative impact on votes. The location, nature of broadcasts and talent, and advertising played a role in determining their impacts. For example, in Buenos Aires proper, radio advertising costs for a few minutes of airtime 
were over $\$ 400$ in 1947 US dollars, with many of the programs consisting of more than 40 actors and actresses. Respectively, in La Rioja the same costs came to a little over five dollars, and programs featured eight actors and actresses in total. ${ }^{3}$ Thus, the impacts and reach varied greatly.

\section{Conclusion}

The influence of various forms of media are felt daily in politics and public discourse. Modern elections are intricately tied to media outlets and the political economy surrounding their use. While the technologies have changed over time, in the last 200 years at least, media have played an important role in elections and revolutions. Our focus is on radio, which has had a political impact since the 1920 s. Once radios became commonplace, they also became a vehicle for politics. In the case of Argentina, this happened in the 1940s and 1950s. While Argentinian elections were not transparent and fraud was rampant, they were not a foregone conclusion. Despite earlier research suggesting that fraud was a key feature in the 1946 election, we argue that the situation was hardly straightforward.

Perón was a master at manipulating crowds, and the radio was well-suited for this purpose. He used gestures and mannerisms to connect with his base. He also utilized radio to enhance the traditional personalistic patron-client relationships that dominated Argentine politics; in fact, he created new patron-client relationships with his effective cultural and economic rhetoric. In addition, Perón made effective use of Eva Duarte's celebrity to attract voters in the urban areas where he had not yet done as well as expected in 1946. Finally, by 1950, he made use of newspapers and journalists, through the government takeover of newspapers, in addition to the radio, to win over hesitant voters and key interest groups.

Based on qualitative and quantitative evidence, we found that Perón's consolidation of power from 1946-1948 (and beyond) was based on the use of media, in addition to courting key interest groups effectively. Moreover, the nationalization of the radio industry by 1948 gave Perón almost complete control over this medium, enhancing his success in the 1948 election. The quantitative evidence suggests that the importance of radio to Perón's electoral success grew substantially from the 1946 to the 1948 elections. Moreover, multivariate analyses showed that radio clearly influenced his victory also in 1946. The situation was a bit more complex in 1948, with Perón gaining among women and certain rural regions in particular. Overall, the qualitative and quantitative evidence suggests that radio had a substantial role in installing Perón in power, leading Argentina further down the path towards institutional instability and authoritarian populism.

3 Broadcasting Stations of the World (1946). Here the values in pesos were converted to US dollars with the exchange rate of $1 \mathrm{Peso}=\$ 0.2681$. While it would be very interesting to analyze the advertising spending and electoral outcomes, here we simply lack the data to do so. 


\section{Bibliography}

\section{Primary sources}

"1946 Yearbook." Broadcasting, 1946, American Radio History.

Broadcasting Stations of the World: According to Country and City, Washington, D.C.: Foreign Broadcast Intelligence Service, War Department, 1946.

Data and Rates of Radio Stations in the Other American Republics and Puerto Rico, Washington, D.C.: United States Office of Inter-American Affairs, 1945.

"El Resultados de Elección en 1946." La Prensa, Buenos Aires, Argentina: February 28, 1946.

IV Censo General de la Nación. Census. Tomo I: Censo de Población. Buenos Aires, Argentina: Presidencia de la Nación y Ministerio de Asuntos Técnicos, 1947.

La Prensa, 1946 and 1948. Buenos Aires, Argentina: Newspaper.

"Memorandum of Conversation: Participants Carl Spaeth and Charles R. Burrows." United States Government Document. Washington, D.C., August 12, 1946. University of Delaware Library.

Milton Bracker. "Perón's Challenge to the Free Press: Argentina's Dictator Controls Most Papers but La Prensa and La Nacion Still Resist Him." New York Times. March 5, 1950. Proquest Historical Newspapers: The New York Times (1851-2009).

Morrow, Edward A. "Perón Paper Bars End of Curbs Now: Answer to Foe's Broadcast Says the Opposition Must End Acts of 'War' First." New York Times. July 30, 1955. Proquest Historical Newspapers: The New York Times (1851-2009).

Mystery Solved. Daily Report: Briefs, Argentina. Trujillo: United, June 4, 1953. Foreign Broadcast Information Service.

"Perón Aide Bars Radio Time to Foe: Radical Leader Fails in Bid to Broadcast---Opposition Setting New Policy." New York Times. July 8, 1955. Proquest Historical Newspapers: The New York Times (1851-2009).

PERÓN, Juan Domingo. Juan D. Perón Plaza de Mayo October 17, 1945 Speech. MP3. Buenos Aires, Argentina, 1945. Biblioteca del Congreso de la Nación Argentina.

Radio Belgrano (LRY). Daily Report: Briefs. Washington D.C.: United States Foreign Radio Broadcasts, June 9, 1947. Washington, D.C.: Foreign Broadcast Information Service, War Department.

"Resultados de las Tres Últimas Elecciones Metropolitanas de Presidente y Diputados." La Nación, February 23, 1946.

SARMIENTO, Domingo Faustino (1998), Facundo: Or, Civilization and Barbarianism. New York: Penguin Classics.

United Nations Educational, Scientific and Cultural Organization. World Communications, Press, Radio, Film, and Television. 3rd ed. Paris: United Nations Educational, Scientific and Cultural Organization, 1956.

"What Are the Facts About Radio Abroad?" Sponsor, July 14, 1952.

\section{References}

ALSTON, Lee J, GALLO Andrés A. (2010), "Electoral Fraud, the Rise of Perón and Demise of Checks and Balances in Argentina", Explorations in Economic History, 47 (2), 179-197.

ANDERSON, Benedict (2006), Imagined Communities: Reflections on the Origin and Spread of Nationalism, New York, New York, Verso.

BANKS, Arthur S. (1973), “Cross-National Time Series, 1815-1973”, ICPSR, Ann Arbor, MI: Inter-university Consortium for Political and Social Research. 
BOAS, Taylor C. (2005), "Television and Neopopulism in Latin America: Media Effects in Brazil and Peru", Latin American Research Review,40 (2), 27-49.

BOLT, Jutta, VAN ZANDEN, Jan Luiten (2013), "The First Update of the Maddison Project: Re-Estimating Growth before 1820", Maddison Project Working Paper WP-4, University of Groningen, January. Groeningen.

BRUSCO, Valeria, NAZARENO, Marcelo, STOKES Susan Carol (2004), "Vote Buying in Argentina”, Latin American Research Review, 39 (2), 66-88.

CALVO, Ernesto, MURILLO Maria Victoria (2004), "Who Delivers? Partisan Clients in the Argentine Electoral Market", American Journal of Political Science, 48 (4), 742-757.

CHAMOSA, Oscar (2010), The Argentine Folklore Movement: Sugar Elites, Criollo Workers, and the Politics of Cultural Nationalism, 1900-1955, Tucson, Arizona, University of Arizona Press.

CLAXTON, Robert H. (2007), From Parsifal to Perón: Early Radio in Argentina, 1920-1944, Gainesville, University Press of Florida.

CRASSWELLER, Robert D. (1987), Perón and the Enigmas of Argentina, New York, New York, W. W. Norton \& Company.

FOX, Elizabeth, FOX, Fox de Cardona (1997), Latin American Broadcasting: From Tango to Telenovela, Bloomington, IN, Indiana University Press,.

GIBSON, Edward L., SUÁREZ-CAO, Julieta (2010), "Federalized Party Systems and Subnational Party Competition: Theory and an Empirical Application to Argentina", Comparative Politics, 43 (1), 21-39.

GRAHAM-YOOLL, Andrew (1975), "The Argentinian Press under Perón”, Index on Censorship, 4 (1), 47-53.

HILMES, Michele, LOVIGLIO Jason (2002), "Introduction”, in Michele Hilmes and Jason Loviglio (eds.), Radio Reader: Essays in the Cultural History of Radio, New York, New York, Routledge, xi-xv. HORVATH, Ricardo (1986), La trama secreta de la radiodifusión Argentina: Los dueños de la información electrónica y el largo brazo de su poder, Buenos Aires, Ediciones Unidad.

JAMES, Daniel (1993), Resistance and Integration: Perónism and the Argentine Working Class, 1946-1976, Cambridge Latin American Studies, New York, N.Y., Cambridge University Press.

KARUSH, Matthew B. (2012), Culture of Class: Radio and Cinema in the Making of a Divided Argentina, 1920-1946, Durham, North Carolina, Duke University Press.

KEEN, Benjamin, HAYNES, Keith. (2009), A History of Latin America. 8th ed. Boston, Mass., Houghton Mifflin Harcourt.

LEVITSKY, Steven (2003), "From Labor Politics to Machine Politics: The Transformation of Party-Union Linkages in Argentine Peronism, 1983-1999", Latin American Research Review, 38 (3), 3-36.

LITTLE, Walter (1973a), "Electoral Aspects of Peronism, 1946-1954", Journal of Interamerican Studies and World Affairs, 15 (3), 267-284.

LITTLE, Walter (1973b), "Party and State in Peronist Argentina, 1945-1955", Hispanic American Historical Review, 53 (4), 644-662.

LUNA, Félix (1969), El 45: Crónica de un año decisivo, Argentinos 8, Buenos Aires, Editorial J. Álvarez.

LUNA, Félix (2000), Perón y sus tiempo: La Argentina era una fiesta (1946-1949), Vol. 1. 3 vols. 8th ed. Buenos Aires, Editorial Sudamericana.

LUNA, Félix (2013), Perón y Su Tiempo: La Comunidad Organizada (1950-1952), Vol. 2 of 3. 5th ed. Buenos Aires, Editorial Sudamericana.

MCCAULEY, Michael P. (2002), "Radio's Digital Future: Preserving the Public Interest in the Age of New Media", in Michele Hilmes and Jason Loviglio (eds.), Radio Reader: Essays in the Cultural History of Radio, New York, Routledge, 505-530.

MERCADO, Silvia D. (2013), El inventor del Peronismo: Raúl Apold, el cerebro oculto que cambió la política argentina. 3rd ed. Buenos Aires, Groupo Editorial Planeta S.A.I.C..

MILANESIO, Natalia (2013), Workers Go Shopping in Argentina: The Rise of Popular Consumer Culture, Albuquerque, New Mexico, University of New Mexico Press. 
MILLER, Elmer S. (1979), Los Tobas Argentinos. Armonía y Disonancia en Una Sociedad, Buenos Aires, Siglo Veintiuno Argentina Editorial.

NICHTER, Simeon (2008), "Vote Buying or Turnout Buying? Machine Politics and the Secret Ballot", American Political Science Review, 102 (01), 19-31.

NOGUER, Jorge Eduardo (1985), Radiodifusión en la Argentina, 1st ed., Buenos Aires, Editorial Bien Común.

PLOTKIN, Mariano Ben (2002), Mañana Es San Perón: A Cultural History of Perón's Argentina, 2nd ed., Wilmington, North Carolina, Scholarly Resources Inc..

POTASH, Robert A. (1969), The Army \& Politics in Argentina: 1945-1962; Perón to Frondizi, Vol. 2, Stanford, Stanford University Press.

ROCK, David (1985), Argentina, 1516-1982: From Spanish Colonization to the Falklands War, 2nd ed., Berkeley, University of California Press.

SIRVÉN, Pablo (1984), Perón y los medios de communicación: La conflictiva relación de los gobiernos justicialistas con la prensa, 1943-2011, Buenos Aires, Centro Editor de América Latina.

SMITH, Peter H. (2005), Democracy in Latin America: Political Change in Comparative Perspective, New York, Oxford University Press, 5th ed..

SNOW, Peter G. (1969), "The Class Basis of Argentine Political Parties", American Political Science Review, 63 (1), 163-167.

STRÖMBERG, David (2004), "Radio's Impact on Public Spending", Quarterly Journal of Economics 119, (1), 189-221.

ULANOVSKY, Carlos, MERKIN, Marta, PANNO, Juan Jose, TIJMAN, Gabriela (1996), Días de Radio: Historia de la Radio Argentina, 4th ed., Buenos Aires, Espasa Calpe.

WALTER, Richard J. (1993), Politics and Urban Growth in Buenos Aires: 1910-1942, Cambridge Latin American Studies 74, New York, Cambridge University Press.

WIARDA, Howard J., KLINE, Harvey F. (1985),. "The Latin American Political Process and Its Present Crisis," in Howard J. Wiarda and Harvey F. Kline (eds.), Latin American Politics and Development, 2nd ed., Boulder, Colorado, Westview Press, 106-121. 